\title{
DOI: 10.7596/taksad.v10i4.3138
}

Citation: Ağarı, M. (2021). Historical Roots and Syntactic Nature of Languages. Journal of History Culture and Art Research, 10(4), 32-43. doi: http://dx.doi.org/10.7596/taksad.v10i4.3138

\section{Historical Roots and Syntactic Nature of Languages}

Murat Ağarı ${ }^{1}$

Abstract

All languages have a common, ontological nature, and this nature cannot be changed. Although there are some differences in the fictions of languages, the general course of this ontological nature is the same in all languages. Although we are talking about an ontological nature that is the same in all languages, the differences that exist between languages affect and determine the attitudes of societies that use this language. In another respect, history is a totality of social attitudes. Therefore, the language used by society can affect the attitude of that society. In other words, societies have an attitude in such a way that the language they use is foreseen. So much so that, beyond the fictional difference, even the presence or absence of a word in any language can be decisive of a social attitude. Of course, the presence or absence of a word is a small detail in the whole; but when the peculiar fictions of languages are evaluated as a whole, the effects of social attitudes on history, which is the totality, will be seen more clearly.

In this study, first of all, the concept of "language family" will be focused on by giving the "definition of language". Then, the nature of Turkish will be discussed through the language family fiction and its reflections on history will be discussed. Turkish, English, Arabic and will be sampled throughout the study.

Keywords: Language family, Differences between languages, Indo-European languages, Semitic languages, Altaic languages.

\footnotetext{
${ }^{1}$ Prof. Dr., University of Karabük, Faculty of Letters, Department of History. E-mail: magari@karabuk.edu.tr
} 


\section{Introduction}

Language is described as a means of mutual communication between people and as a system that allows the transfer of feelings, thoughts and desires to others with the help of common rules in terms of sound, shape and meaning. (Korkmaz, 1992: 43). According to another definition, "it is a system of audible signs that people use to tell their prayers" (Banguoğlu, 1974: 9). There is a language definition made over the string. Within the framework of this definition, language is "a system of double-jointed vowel signs specific to a certain human community." (Vardar, 2007: 71). According to the definition, which assumes that language is an agreement, language is "the agreement that people make with words or tools to express their feelings and thoughts" (Hatipoğlu, 1978: 39).

Tahsin Banguoğlu defines the language as "a system of vowel signs that people use to convey meaning". According to him, "we describe some of our feelings, thoughts and wishes by making signs that start with the hand and eyebrow with the eye; but our most perfect means of expression is language" (Banguoğlu, 1974: 10).

Considering all these definitions, we can say that language, as a potential structure, is a tool that people use to agree with each other. Banguoğlu stresses that "speech/parole is a high functioning that is a tax on the son of a person and distinguishes a person from an animal" (Banguoğlu, 1974: 9). The following statements also belong to Banguoğlu: "They must have been formed by supporting the human brain, the organ of thought, with language. So much so that in the end, language has also been a means of thinking. We think by constructing sentences from our native language. When we say these things, we say don't speak for yourself. Without language, feelings and thoughts would not have developed either. The human community could not progress, could not create a civilization. Again, the religious life and the art life, which are taxed to the son of the person, are also based on the language foundation" (Banguoğlu, 1974: 9-10). In this aspect, it is possible to say that language is the tool that allows the mind, which was created as an element that makes sense of existence, to become functional. In other words, language is a system of telling by speaking and writing what is wanted, thought and heard in human communities. From this point of view, it is possible to say that it arises from the need for agreement created by living together (Emre, 1945: 3). Likewise, in terms of structure and functioning, it is a natural communication system revealed by human labor and mind on earth (Eker, 2015: 111) and is a human-specific phenomenon (Demir-Yılmaz, 2016: 15).

\section{The Concept of The Language Family}

At the beginning of the issues that make the language historically important, which can be described in many more ways, is the concept of language family. The language family is a whole formed by languages derived from the same mother tongue and connected to a common origin (Vardar, 2007: 72).

If we leave aside these discussions at the level that may be a different research topic, it is possible to say that the world's languages are divided into various language families in terms of their sources and varieties. The main language families are:

- Indo-European language family,

- Sino-Tibetan language family, 
- Hami-Sami/Afro-Asiatic language family,

- The Ural-Altaic language family,

- The Bantu language family,

- The Caucasian language family,

- The Finno-Ugric language family

- The Austronesian language family,

- Native American language family (Akar, 2012: 15).

Issues such as the relations between languages, similarities and language families have been investigated, and the obvious similarities made one think whether there could be some kind of genetic relationship between languages, and in this context, the types of relations between languages were examined. As a result of the research, it has been determined that there are types of language relations originating from different reasons and the possible reasons for these similarities are listed as historical relations, regional convergence, typological parallels, crossing of independent roots, coincidence and genetic relationship (Açık, 2017: 3).

In our study, we focus on the Indo-European language family, the Semitic language family and the Ural-Altaic language family, and we will make examples through Turkish, Arabic and English.

\section{Indo-European Languages}

Except for Finnish, Hungarian and Estonian, it is a group of languages spoken as a second language acquired in all of Europe, a large part of Asia and America, and some African countries (Akar, 2012: 15). English is in the European branch of this language group and among the Germanic languages. Persian, on the other hand, is in the Asian branch of the same language group and among the Iranian languages (Akar, 2012: 15-16).

\begin{tabular}{|l|l|l|l|l|l|}
\hline \multicolumn{5}{|c|}{ INDO-EUROPEAN LANGUAGES } \\
\hline \multicolumn{2}{|c|}{ ASIAN ARM } & \multicolumn{4}{c|}{ EUROPEAN ARM } \\
\hline INDO-URDU & IRAN & GERMAN & LATIN & SLAV & OTHER \\
\hline Indian & Persian & German & Spanish & Russian & Greek \\
\hline Urdu & Peshtun & English & French & Bulgarian & Albanian \\
\hline Bengali & Oset & Dutch & Portuguese & Serbian & Irish \\
\hline Bihari & Talish & Swedish & Romanian & Bosnian & \\
\hline Pancabi & & Norwegian & & Polish & \\
\hline Gujarati & & & & Macedonian & \\
\hline
\end{tabular}


We can give the main features of the Indo-European language family, the main of which are classified as above:

- There is no vowel harmony in this language group.

- The word does not necessarily have to start with the root.

- The languages in this language group are twisted languages. Some linguists think that English may be a simplistic language. According to them, the simplification of English in terms of form is based on the disappearance of some suffixes over time and the Roman and Greek origin of many words.

- In this language group, words have gender as masculine and feminine.

- Words can contain double vowels/diphthongs.

- Nouns that come after numerical adjectives are plural.

- The sentence structure is "Subject + Predicate + Object". The subject is at the beginning and the predicate is in the middle of the sentence.

- Both prefix and suffix are used.

- Adjectives come before nouns, especially in the Germanic branch.

- The identifier "the" is used at the beginning of the names.

- Comparison is made with the state.

- There are auxiliary verbs/linking verbs in this language group.

- Interrogative sentence is made by placing the auxiliary verb at the beginning of the sentence (Özgüney, 2004: 13-14).

\section{Semitic Languages}

Semitic languages consist of more than 250 languages found and spoken in the Arabian peninsula and North Africa. The main languages of this language group, which is divided into two subgroups as Hami and Semitic, are Arabic, Hebrew, Amhara/Abyssinian, Hausa/Chad, Berber, and the dead languages Coptic, Akkadian and Aramaic (Akar, 2012:18).

\begin{tabular}{|c|c|c|c|c|c|}
\hline \multicolumn{6}{|c|}{ SEMITIC LANGUAGES } \\
\hline \multicolumn{3}{|c|}{ WESTERN SEMITIC LANGUAGES } & \multicolumn{3}{|c|}{ EASTERN SEMITIC LANGUAGES } \\
\hline \multicolumn{2}{|c|}{$\begin{array}{c}\text { SOUTHWEST SEMITIC } \\
\text { LANGUAGES }\end{array}$} & \multicolumn{2}{|c|}{$\begin{array}{l}\text { NORTHWEST SEMITIC } \\
\text { LANGUAGES }\end{array}$} & \multicolumn{2}{|c|}{ AKKADIAN LANGUAGE } \\
\hline Arabic & Abash Language & $\begin{array}{l}\text { Canaanite } \\
\text { Languages }\end{array}$ & $\begin{array}{c}\text { Aramaic } \\
\text { Languages }\end{array}$ & Babylonian & Assyrian \\
\hline
\end{tabular}


Arabic is a member of the Semitic language family. It is thought that the Semitic language group comes from a Hami-Semitic root that includes the ancient Egyptian language. Semitic languages are divided into two major branches as Eastern and Western (Aydın, 2018: 3).

The main features of Arabic, which belongs to the Semitic language family, are as follows:

- In Arabic, the root of the verb consists of three consonants and there are no vowels. Fathah, kasrah and dammah, called "harakah", form vowels.

- Arabic has inflected language feature.

- In Arabic, the gender of the words, masculine and feminine, is in question. Words are divided into two as masculine/muzakkar and feminine/muannas.

- The duties of words in sentences are revealed according to i'râb. ${ }^{2}$

- The main element in Arabic is at the beginning (Nalçakan, 2008: 5).

\section{Altaic Languages}

According to the common opinion, Altaic Languages is a language group formed by the combination of Turkish, Mongolian, Manchu-Tungusian, Korean and Japanese. With nearly thirty dialects, Turkish is the most common branch of the Altaic languages and is the most spoken language among them. (Akar, 2012: 18-19). Although there are different opinions and thoughts that contradict each other, the Turkish language is generally accepted as a language belonging to the Ural-Altaic family among the world languages today (Karamanlıoğlu, 1972: 11).

Studies of Altaic languages started with Strahlenberg's trial of Tatar Languages family, which includes Finno-Ugric, Mongolian, Manchu-Tungus, Turkish and Caucasian languages. Strahlenberg, who was exiled as a prisoner of war to Siberia by Russia, collected material on the languages and cultures of the Siberian peoples for 13 years. After returning to his country, he evaluated this material in a book. (1730) In this way, the discussion of the Ural-Altaic language union began. Subsequent researchers have revised and narrowed or expanded its classification. (YIlmaz, 2018:1). This language group formed the Altaic languages part of the language family called Ural-Altaic languages. In recent years, the Ural languages of this language family have been evaluated as Finno-Ugric languages, and the Altaic languages are evaluated in separate groups as Altaic Languages. Thus, both groups began to be considered independently.

The features that distinguish the Ural-Altaic languages from the Indo-European and Semitic languages can be listed as follows:

- There is a harmony of sounds in the Ural-Altaic languages.

- There is no Word gender in this language group.

- There is no suffix of "-al/ harf tarif" and identifier "the".

\footnotetext{
${ }^{2}$ I'rab is described as follows: "The change that occurs at the end of words as a word or appreciation as a result of the change of amyil is called "i'rab"." See: Mehmet Sıdık Özalp (2019/1). "The Phenomenon of I'râb in the Arabic Language", Journal of Uludag University Faculty of Theology, N: 28, p. 198.
} 
- Verbs and nouns are taken with suffixes.

- A possessive suffix is used in conjugation.

- In adjective phrases, adjectives take place in front of the noun.

- There are suffixes, not prefixes.

- Plural suffix(s) are not used after numbers.

- There is a separate question attachment.

- The verb to be is used instead of to have as an auxiliary verb.

- Comparison is made with the suffix of from/-den.

- There is a separate question attachment (Akar, 2012: 23).

\begin{tabular}{|l|l|l|l|l|l|}
\hline \multicolumn{5}{|l|}{ URAL-ALTAIC LANGUAGES } \\
\hline \multicolumn{2}{|l|}{ URALiC LANGUAGES } & \multicolumn{4}{l|}{ ALTAIC LANGUAGES } \\
\hline $\begin{array}{l}\text { Fin-Ugor } \\
\text { Languages }\end{array}$ & $\begin{array}{l}\text { Samoyed } \\
\text { Languages }\end{array}$ & $\begin{array}{l}\text { Mançu- } \\
\text { Tunguz }\end{array}$ & $\begin{array}{l}\text { Turkish } \\
\text { Languages }\end{array}$ & $\begin{array}{l}\text { Mongolian } \\
\text { Languages }\end{array}$ & $\begin{array}{l}\text { Korean- } \\
\text { Japanese }\end{array}$ \\
\hline
\end{tabular}

The main features of the Altaic language group as it is common can be listed as follows:

- The common features among Altaic languages in terms of sound, structure and syntax cause these languages to be gathered under a separate group.

- This language group has vowel harmony. However, this vowel harmony was broken in Manchu-Tungus and modern Turkish dialects New Uyghur and Uzbek.

- Altaic languages are penultimate languages. In these languages, words are made by adding certain suffixes to the root or stem.

- There are only suffixes in this language group. As there is no prefix, there is no suffix placed in the word.

- The sentence construction in Altaic languages is "Subject + Object + Predicate". In other words, the predicate is at the end and it is the most defining feature that distinguishes these languages in Indo-European and Semitic language groups.

- In this language group, the noun phrases come before the phrase. In Indo-European and Semitic language groups, there are different genitive features. In adjective phrases, unlike the Semitic language group, there is no harmony between the phrase and the phrase in terms of case, gender and number.

- Nouns that follow plurality numbers do not take plural suffix(s). However, in English, the noun becomes plural in numbers two or more. In Arabic, the situation is different and there are various situations between numbers and counts. 
- There is no gender discrimination in Altaic languages. In other words, there are no masculine or feminine word groups. ${ }^{3}$

When we need to classify languages other than language families, a table will appear as follows:

\section{- Additional Languages}

New words are obtained by adding various suffixes to the beginning or end of the words in this language group. As an example, we can give the word "göz-lük-çü-lük". Ural-Altaic languages are languages that fall into this group.

\section{- Inflected Languages}

Languages in which new words are derived by inflecting the word roots are inflected languages. New words such as cruel, oppressed, and cruelty have been made from the Arabic z-I-m infinitive. Indo-European and Semitic languages fall into this group.

\section{- Monosyllabic Languages}

- Monosyllabic Languages

Languages in which each product is a root are monosyllabic languages. The root in question does not take any attachments and is in a bare state. It is a linguistic indicator of the structure of each syllable. The definitions of those used in these languages are distinctive from those listed. This group includes Chinese, Vietnamese and Tibetan languages. ${ }^{4}$

As can be understood from the above classifications, Indo-European languages and Semitic languages show similar characteristics. Because both language groups are similar to each other in terms of the location of the predicate and the fact that it is additive. The Altaic language group, on the other hand, differs from the other two language groups in terms of both being agglutinative and having the predicate at the end.

So, we can construct these two language groups as follows:

Indo-European-Semitic language groups:

Subject + Predicate + Object + Other complements

Ural-Altaic language groups:

Subject + Other complements + Object + Predicate

\section{Syntactic Nature}

The relationship of being with language is an obligatory one. In this context, we have to evaluate the relationship of the entity with the language as a feature that allows us to understand the

\footnotetext{
${ }^{3}$ For features of Ural-Altaic languages, see: A. Akar, Turkish Language History, pp. 23, 33-34; G. Öz Açık, Language Kinship, pp. 109-110; Fuat Bozkurt (2012). Language of Turks, Konya, Education Publications, pp. 46-47; Nurettin Demir-Emine Yılmaz, Türk Dili El Kitabı, pp. 53-54.

${ }^{4}$ For more information on this, see: A. Akar, Turkish Language History, pp. 20-21; Sezai Güneş (1999). Turkish Language Grammar, İzmir, pp. 14-15.
} 
nature of the entity (Torun, 2019: 95). As can be seen, there are obvious differences between Altaic Turkish and Indo-European and Semitic languages. In order to understand the place of Turkish, we can specify the features that distinguish Turkish from other languages as follows:

- Turkish is a penultimate language. Relationships between words are made with ending inflections and prepositions. Indo-European languages and Semitic languages are among the group of pre-added languages.

- The syntax of "subordinate/main sentence" with conjunctions such as "ki" in Persian, "that, which" in English, and "allazi, allati" in Arabic does not exist in Turkish. The equivalent of these constructions in Turkish are adjective-verb/ ortaç and adverb-verb/ulaç.

There is no suffix of "-al/ harf tarif" and identifier of "the" as can be seen in Semitic languages and many of Indian-Europen languages in Turkish. Because in Turkish, names are the name of a species, not a single object. Other than these, the certainty / uncertainty is only understood from the context.

- Again, with some Indo-European languages, masculinity, femininity, which is a feature of the Semitic languages and, therefore, the Arabic language, is not found in Turkish.

- Turkish Arabic does not have the feature of duality/deuteronomy.

- In many languages, including Indo-European languages and Semitic languages, the same word can be both a noun and a verb root. However, this feature is not available in Turkish. When we look at the same things, we see that they are either not roots or that they are forms that have arisen later.

- The question structure to be answered with a yes-no question is made by changing the word

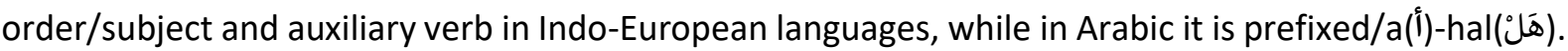
In Turkish, the question structure is obtained with the ending -mi suffix.

- There is an important feature in numbers that distinguishes Turkish from other languages. Accordingly, decimal words such as twenty, thirty, forty, fifty are independent of unity words such as two, three, four, and five. For example, the word grouping that is in the form of "two-twenty, threethirty, four-forty, five-fifty" in English is "ithnan-ishrun, thalatha-thalathun, arbaa-arbaun, khamsahkhamsun" in Arabic. As can be understood from these two examples, there is a unity of origin between them. However, there is no connection between "iki-yirmi, üç-otuz, dört-kırk and beş-elli" in Turkish.

Apart from the differences that we have mentioned above, there are also phonetically related differences.

- There is vowel harmony in Turkish. This feature, which is also found in other Ural-Altaic languages, is not present in the Semitic languages and Indo-European languages.

- Similar to the previous title, the number of vowels in Turkish is higher than in many languages. There are eight vowels, as is customary, and nine in some dialects. Because of these eight vowels, Turkish can even be called a vowel language. The vowels in English are A, E, I, O, and U. In Arabic, on the other hand, there are only three sounds as fathah, kasrah and dammah.

- In Turkish, $C, F, \breve{G}, H, L, M, N, R, V$ and $Z$ are consonants that are not found the beginning. In addition, $B, C, D$, and $g$ are consonants that are not found at the end. Arabic and English have similar qualities too. But these and similar features in these two languages are incompatible with Turkish. 
- The feature called consonant accumulation does not exist in Turkish. In other words, it is not possible to accumulate more than one consonant at the beginning of a syllable or to have more than one consonant side by side at the end of a syllable (some couples are an exception). For example, words such as stres/stress, kral/king, sfenks/sphinx, klasik/classic in Indo-European languages and words such as vacd, zikr and ilm in Arabic are not found in Turkish.

- Both open and closed syllables are available in Turkish. In this aspect, many world languages are similar to each other.

- The only consonants in the word in Turkish are necessarily syllables with the vowel after them. For example, the word a-şa-ğı-da-ki is not spelled as aş-ağ-ıd-ak-i.

There are other features other than the ones we mentioned above. The mentioned features are the distinguishing features of Turkish. These features of Turkish, whose first known texts belong to the first half of the 8th century, and whose first written dictionary belongs to the second half of the 11th century, have not changed since those days. ${ }^{5}$

\section{Historical Approach}

Above, we have highlighted the differences between Altaic languages, Indo-European languages and Semitic languages. It seems that there are significant differences between Turkish and other world languages at many points, especially the place of the predicate. In our opinion, the location of the predicate emerges as an antecedent difference at this point.

When we look at societies speaking European and Semitic languages syntactically, we will see the following table:

- Subject + Predicate + Object + Other complements

It is also possible to give this syntax as "Name + Action + Name + Name". The fact that the action is in the middle according to the structure in question shows that the mentioned societies are interested in the action rather than the object, and that the action is formative rather than compiling. In short, societies using Indo-European and Semitic languages shape the action and consider the object of action based on action.

As an Altaic language, Turkish is different:

- Subject + Other complements + Object + Predicate

It is also possible to give this syntax as "Name + Noun + Noun + Action". By looking at the template in question, it is possible to say that the Turks or the nations that use this syntactic structure are more concerned with the object than with the action. The fact that the action is at the end shows that historical activities have a compiler and aggregative nature.

When we show both templates one after the other, the following table will appear and the subject will be better understood:

\footnotetext{
${ }^{5}$ For more information on the subject, see: Ahmet Bican Ercilasun (2013). "The Place of Turkish among World Languages", Language Studies, N. 12 (Spring), p. 17.
} 
Indo-European/Semitic:

Noun/Subject + Verb/Verb + Noun/Object + Noun/Complement $=$ Predicate logic

Ural-Altaic:

Noun/Subject + Noun/Complement + Noun/Object + Action/Predicate=Object logic

While the Indo-European and Semitic languages with a predicate-logic structure tend to objects with an action-based understanding, the Ural-Altaic languages with an object logic structure perform the action with an object-based understanding. This difference of understanding enables societies that use similar languages to understand each other more easily. In this respect, although they are different language groups, the Indo-European language group and the Semitic language group are close to each other in terms of mentality.

Another issue that needs to be added in the framework we are trying to explain will be the creation phenomenon of both language constructs. As it will be remembered, we gave the IndoEuropean language construct as follows:

- Subject + Predicate + Object + Other complements

It is also possible to interpret this fiction as follows:

- Subject + Predicate $=$ Object + Other complements

The fiction we have given is a creation fiction as follows (Ağarı, 2004: 110).

Subject $($ God $)+$ Predicate $($ Creation $)=$ Object $($ Cosmos $)$

From this point of view, we can easily say that the language construct in question is a beginning and a creation construct. However, it is not possible to say the same things for the Altaic language group. As it will be remembered, we gave the Ural-Altaic language setup as follows:

- Subject + Other complements + Object + Predicate

There is no possibility to partition this template in a meaningful way as in the other template. Therefore, it is a necessity to evaluate this table as a whole. From this point of view, it is possible to say that the Ural-Altaic language construct is a secular/worldly construct rather than a creation construct, and is applied without partitioning.

\section{Result}

From a syntactic point of view, we can say that the Indo-European, Semitic and Ural-Altaic language families are located on the main axis of the world. As a means of communication and agreement, these language families appear in two different sequences. These different sequences force us to consider different thought constructs.

First of all, we have tried to address our approach to these languages in terms of being actionoriented or object-oriented. As a result, we have seen that Turkish, which has the syntax of "Subject + Object + Predicate", is an object logic language, while languages belonging to Indo-European and Semitic language groups, which have the syntax of "Subject + Predicate + Object", are verb logic. At 
the same time, we stated that the ending of the verb in Turkish shows that the historical activities of societies using these languages are of a compiler and aggregative nature.

Secondly, we approached these languages through the phenomenon of creation and stated that the "Subject + Predicate + Object" syntax can be constructed as "Subject + Predicate = Object". Based on this, we have come to the conclusion that languages with such a fiction are more suitable for the phenomenon of creation. On the other hand, we stated that the fiction in the form of "Subject + Object + Predicate" is not suitable for division and therefore it is more appropriate to consider it as secular/worldly.

Finally, it is worth noting that: History records what happened. In that case, there is the character of "be" on the basis of history (Ağarı, 2002: 108). Similarly, there is a "be" character in the nature of language. The verb "to be" in English is a striking example of this. Likewise, the verb ${ }^{1}$ in Arabic, the verb بودن in Persian and the verb -imek in Turkish are other examples that reflect the characters of "ol" in the language. Therefore, "be" characters are the elements that shape both history and language.

\section{References}

Açık, Gülhan Öz (2017), An Evaluation of Linguistic Kinship and Altaic Kinship Studies, Unpublished Doctoral Thesis, Hacettepe Unv. Social Sciences Inst., Ankara.

Ağarı, Murat, (2004). "History/Nature and Human Context in the Perception of Ontological History", Islamic Studies, V: 17, N: 2, p. 110.

Akar, Ali, (2012). Turkish Language History, İstanbul: Ötüken Publications.

Aydın, Mustafa, (2018). “Arabic language”, Journal of Faculty of Education, Y: 4, N: 1, p. 3.

Banguoğlu, Tahsin, (1974). Grammar of Turkish, i̇stanbul: Baha Printing House.

Bozkurt, Fuat, (2012). Language of Turks, Konya, Education Publications, Fifth Edit.

Demir, Nurettin-Emine Yilmaz, (2016). Turkish Language Handbook, Ankara: Grafiker Publ.

Eker, Suer, (2015). "An Overview of Modern Turkic Languages from the Main Altai", Turkish Culture Handbook, Ankara: Grafiker Publ., p. 111.

Emre, Ahmet Cevat, (1945). Turkish Grammar, İstanbul: Turkish Language Association Publ.

Ercilasun, Ahmet Bican, (2013). "The Place of Turkish among World Languages", Language Studies, N: 12, Spring, p. 17. 
Güneş, Sezai, (1999), Turkish Language Knowledge, İzmir.

Hatipoğlu, Vecihe, (1978). Glossary of Grammar Terms, Ankara: Ankara University Faculty of Language, History and Geography Publ.

Karamanlıoğlu, Ali, (1972). Turkish Language-Where Does It Come From, Where Is It Going?, İstanbul Hareket Publ.

Korkmaz, Zeynep, (1992). Glossary of Grammar Terms, Ankara: Turkish Language Association Publ.

Nalçakan, Zübeyt, (2008). Comparison of Noun and Verb Sentences in Arabic and Turkish, Unpublished Master's Thesis, Sütçü İmam Unv. Social Sciences Inst., Kahramanmaraş.

Özalp, Mehmet Sıdık, (2019/1). "The Phenomenon of I'râb in the Arabic Language”, Journal of Uludag University Faculty of Theology, N: 28, p. 198.

Özgüney, Hakkı Serkan, (2004). Examining English and Turkish Syntactic Differences in Terms of Language Families, Unpublished Master's Thesis, Ataturk Unv. Social Sciences Inst., Erzurum.

Torun, Tuğba, (2019). "Being and Language”, Journal of Duzce University Faculty of Theology, V. III, N. 2, p. 95.

Vardar, Berke, (2007). Annotated Glossary of Linguistics Terms, İstanbul: Multilingual Publ.

Yılmaz, Emine, (2018). "Studies in Altaic Languages in the Early Two Millenniums: Studies, Methods, Trends", Turkic Linguistics and Philology, (1/1), p. 1 